\title{
Microbial acetone oxidation in coastal seawater
}

\section{Joanna L. Dixon*, Rachael Beale, Stephanie L. Sargeant, Glen A. Tarran and Philip D. Nightingale}

Plymouth Marine Laboratory, Prospect Place, Plymouth, UK

\section{Edited by:}

Colin Murrell, University of East

Anglia, UK

Anne E. Taylor, Oregon State

University, USA

Jonathan Williams, Max Planck

Institute, Germany

${ }^{*}$ Correspondence:

Joanna L. Dixon, Plymouth Marine Laboratory, Prospect Place, West Hoe, Plymouth, Devon PL1 3DH, UK e-mail: jod@pml.ac.uk

\section{Reviewed by:}

\begin{abstract}
Acetone is an important oxygenated volatile organic compound (OVOC) in the troposphere where it influences the oxidizing capacity of the atmosphere. However, the air-sea flux is not well quantified, in part due to a lack of knowledge regarding which processes control oceanic concentrations, and, specifically whether microbial oxidation to $\mathrm{CO}_{2}$ represents a significant loss process. We demonstrate that ${ }^{14} \mathrm{C}$ labeled acetone can be used to determine microbial oxidation to ${ }^{14} \mathrm{CO}_{2}$. Linear microbial rates of acetone oxidation to $\mathrm{CO}_{2}$ were observed for between 0.75-3.5 $\mathrm{h}$ at a seasonally eutrophic coastal station located in the western English Channel (L4). A kinetic experiment in summer at station $L 4$ gave

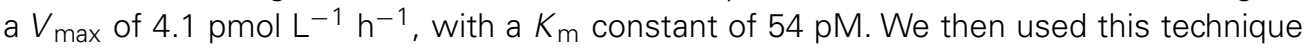
to obtain microbial acetone loss rates ranging between 1.2 and $42 \mathrm{pmol} \mathrm{L}^{-1} \mathrm{~h}^{-1}$. (monthly averages) over an annual cycle at $L 4$, with maximum rates observed during winter months. The biological turnover time of acetone (in situ concentration divided by microbial oxidation rate) in surface waters varied from $\sim 3$ days in February 2011, when in situ concentrations were $3 \pm 1 \mathrm{nM}$, to $>240$ days in June 2011, when concentrations were more than twofold higher at $7.5 \pm 0.7 \mathrm{nM}$. These relatively low marine microbial acetone oxidation rates, when normalized to in situ concentrations, suggest that marine microbes preferentially utilize other OVOCs such as methanol and acetaldehyde.
\end{abstract}

Keywords: bacteria, kinetics, acetone oxidation, Western English Channel (L4), radioactive labeling, seasonality, acetone turnover

\section{INTRODUCTION}

Acetone is a ubiquitous oxygenated volatile organic compound (OVOC) in the troposphere [e.g., Singh et al., 1995, 2003; Lewis et al., 2005], and is thought to play an important role in the chemistry of the atmosphere by sequestering nitrogen oxides, and by providing $\mathrm{HO}_{\mathrm{x}}$ radicals through photolysis (Singh et al., 1995; Wennberg et al., 1998), thus influencing the oxidizing capacity and ozone formation (Singh et al., 2001). The composition of OVOCs in the troposphere and lower stratosphere is dominated by acetone, acetaldehyde, and methanol, e.g., Read et al. (2012). Total global sources of acetone range between 37 and 95 million tons per year (Singh et al., 2000, 2001, 2004; Jacob et al., 2002). Primary terrestrial, e.g., pasture and forest emissions and secondary anthropogenic sources (including biogenic propane oxidation) account for approximately half of known acetone sources (Singh et al., 2000). The oceans are thought to play a major role in controlling atmospheric acetone levels (Fischer et al., 2012), although whether the oceans currently act as a net source or sink to the atmosphere is not clear (Williams et al., 2004; Lewis et al., 2005; Marandino et al., 2005; Taddei et al., 2009; Fischer et al., 2012). However, recent data suggest that the North and South oligotrophic gyres of the Atlantic Ocean are a source of acetone to the atmosphere, whilst near airsea equilibrium conditions dominates over equatorial waters, and temperate open ocean regions (high northern and southern latitudes) show a flux from the atmosphere to the oceans (Beale et al., 2013).

Acetone is thought to be produced photochemically in seawater from chromophoric dissolved organic matter (Mopper and Stahovec, 1986; Kieber et al., 1990; Mopper et al., 1991; de Bruyn et al.,
2011; Dixon et al., 2013a), with strong diurnal variability (Zhou and Mopper, 1997). Acetone production due to photochemical processes was recently estimated at $48-100 \%$ of gross production for remote Atlantic Ocean surface waters (Dixon et al., 2013a). Biological production of substantial amounts of acetone (up to $8.7 \mathrm{mM}$ ) by cultured marine Vibrio species during degradation of leucine has also been reported (Nemecek-Marshall et al., 1995). Acetone is also an intermediate in the metabolism of propane, and is converted, via acetol to either acetaldehyde ( + formaldehyde), acetic acid (+formaldehyde) or ultimately to pyruvic acid by a number of bacteria such as Rhodococcus and Mycobacterium. As both of these species are widespread in terrestrial and marine environments (Hartmans and de Bont, 1986; Ashraf et al., 1994), biological production of acetone is considered likely in agreement with recent marine incubation experiments (Dixon et al., 2013a).

Acetone losses in seawater are less well understood. Previous bacterial culture experiments have shown microbial uptake of acetone (Rathbun et al., 1982; Sluis and Ensign, 1997) with insignificant losses due to direct photolysis in fresh and riverine waters (Rathbun et al., 1982). Loss of acetone in seawater samples from a coastal station in the Pacific Ocean $(33.6 \mathrm{~N}, 118 \mathrm{~W})$ have recently suggested a short half-life of $5.8 \pm 2.4 \mathrm{~h}$ with significant diurnal and seasonal variability (higher loss rates observed during winter and earlier in the day, de Bruyn et al., 2013). However, this contrasts with estimates from surface open ocean Atlantic waters where a comparison of in situ acetone concentrations with microbial oxidation rates from incubation experiments suggest much longer biological lifetimes ranging between 3 and 82 days (Beale 
et al., 2013; Dixon et al., 2013a). Acetone oxidation rates have been shown to linearly positively correlate with bacterial production (Dixon et al., 2013a), and an inverse linear relationship has also been observed between acetone seawater concentrations and bacterial production (Beale et al., 2013). Thus, despite relatively low microbial acetone oxidation rates (compared to other OVOCs like methanol and acetaldehyde, Dixon et al., 2011a,b, 2013a; Dixon and Nightingale, 2012) these relationships suggest that as bacterial production increases, so does the rate of microbial acetone oxidation, leading to a reduction in the in situ concentration of acetone.

The aim of this study was to make a comprehensive assessment of the range and significance of microbial acetone oxidation rates over an annual cycle at a coastal observatory situated in the western English Channel.

\section{MATERIALS AND METHODS}

We have used a radiochemical technique with pico-molar additions of ${ }^{14} \mathrm{C}$ labeled acetone $\left({ }^{14} \mathrm{CH}_{3} \mathrm{CO}^{14} \mathrm{CH}_{3}\right)$ to seawater to determine the microbial transformation (oxidation) of acetone to carbon dioxide, in a similar approach to that of Dixon et al. (2011a) for ${ }^{14}$ C labeled methanol.

\section{SAMPLE COLLECTION}

Surface water samples $(\leq 10 \mathrm{~m})$ were collected from a long term monitoring station, situated approximately 10 nautical miles south-west of Plymouth, called L4 (50.3N, 04.22W, water depth $\sim 55 \mathrm{~m}$, Smyth etal., 2010). Samples were pumped directly into acid-washed quartz Duran bottles and stored in the dark for the $2-3 \mathrm{~h}$ transit back to the laboratory. Labeled ${ }^{14} \mathrm{C}$ acetone was purchased from American Radiolabeled Chemicals, Inc with a specific activity of $30 \mathrm{Ci} \mathrm{mmol}^{-1}$ (ARC0469, neat liquid in sealed ampoule). Primary stocks were made by diluting $1 \mathrm{mCi}$ into $40 \mathrm{mls}$ of $18 \mathrm{M} \Omega$ Milli $\mathrm{Q}$ water $\left(0.025 \mathrm{mCi} \mathrm{mL}^{-1}\right)$ and were stored in gas-tight amber vials in the dark at $4^{\circ} \mathrm{C}$. Stability and storage trials suggested a loss in activity of $<5 \%$ over 12 months. Addition volumes of ${ }^{14} \mathrm{C}$ acetone to seawater samples were always $<1 \%$ of the sample volume and typically $\leq 5 \%$ of the label was used during incubations $\leq 3.5 \mathrm{~h}$.

\section{TIME COURSE EXPERIMENTS}

Time course experiments were initially carried out to determine the period of linear incorporation of the ${ }^{14} \mathrm{Clabel}$. Labeled acetone $\left({ }^{14} \mathrm{C}\right)$ was added to seawater samples to yield final concentrations of 40-90 pM (2700-6100 disintegrations per minute $\mathrm{mL}^{-1}$ ) depending on the experiment (Figure 1). Samples were incubated in acid washed polycarbonate bottles in the dark for between $<1-6.5 \mathrm{~h}$ at in situ sea surface temperature. At selected times, triplicate sub-samples were taken to assess microbial oxidation to ${ }^{14} \mathrm{CO}_{2}$. Oxidation of ${ }^{14} \mathrm{C}$ labeled acetone to ${ }^{14} \mathrm{CO}_{2}$ was determined by pipetting $1 \mathrm{ml}$ samples into $2 \mathrm{ml}$ micro centrifuge tubes and adding $0.5 \mathrm{ml}$ of $\mathrm{SrCl}_{2} \cdot 6 \mathrm{H}_{2} \mathrm{O}(1 \mathrm{M})$, to precipitate the ${ }^{14} \mathrm{CO}_{2}$ as $\mathrm{Sr}^{14} \mathrm{CO}_{3}, 20 \mu \mathrm{l}$ of $\mathrm{NaOH}(1 \mathrm{M})$, to neutralize the $\mathrm{HCl}$ produced, and $100 \mu \mathrm{l}$ of $\mathrm{Na}_{2} \mathrm{CO}_{3}(1 \mathrm{M})$, to ensure adequate pellet formation (Connell et al., 1997; Goodwin et al., 1998). After centrifugation the supernatant was aspirated, the pellet washed twice

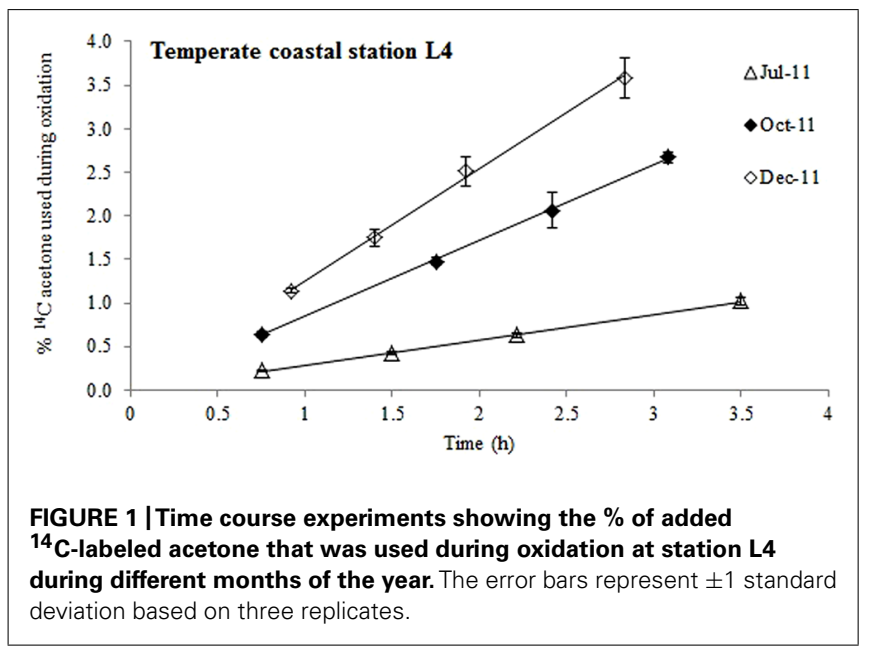

with ethanol (80\%), resuspended in $1 \mathrm{ml}$ of concentrated $\mathrm{NaOH}$ solution $(\sim 10 \mathrm{nM})$ that had been adjusted to a $\mathrm{pH}$ of 11.7 , before addition of Optiphase HiSafe III to create a slurry. The samples were vortex mixed and stored in the dark for $>24 \mathrm{~h}$ before being analyzed on a scintillation counter (Tricarb 3100 or 2910, Perkin Elmer). This period ensures that any chemiluminescence arising from interactions between $\mathrm{NaOH}$ and Optiphase scintillant subside (Kiene and Hoffmann Williams, 1998).

\section{KINETIC DETERMINATIONS}

The kinetics of microbial acetone oxidation were investigated at L4 during February and June 2011 using $1.0 \mathrm{ml}$ surface seawater samples. Surface samples received an addition of ${ }^{14} \mathrm{C}$-labeled acetone, and a series of tubes for microbial oxidation were treated to yield a range of ${ }^{14} \mathrm{C}$ concentrations between 2 and $47 \mathrm{nM}$ ( $\sim 2.5 \%$ of added ${ }^{14} \mathrm{C}$ acetone was oxidized) during February and between 6 and $1006 \mathrm{pM}$ (1.4-5.5\% of added ${ }^{14} \mathrm{C}$ acetone was oxidized) during June 2011. Samples were incubated in screw topped, O-ring sealed micro tubes in the dark at in situ temperature. Three replicates from each acetone concentration were processed, as detailed above, after approximately $1 \mathrm{~h}$ incubation period.

\section{ACETONE OXIDATION RATES}

Triplicate seawater samples $(1 \mathrm{ml})$ were amended with ${ }^{14} \mathrm{C}$ labeled acetone as detailed previously. Microbial acetone oxidation rates (pmol L ${ }^{-1} \mathrm{~h}^{-1}$ ) were calculated by multiplying the sample counts $\left(\mathrm{nCi} \mathrm{mL} \mathrm{m}^{-1} \mathrm{~h}^{-1}\right.$, where $\left.1 \mathrm{Ci}=3.7 \times 10^{10} \mathrm{~Bq}\right)$ by the specific activity of ${ }^{14} \mathrm{C}$ acetone $\left(30 \mathrm{Ci} \mathrm{mmol}^{-1}\right)$. All rates were corrected by subtracting killed sample counts (Trichloroacetic acid, TCA, 5\% final concentration) to correct for non-biological processes. TCA is regularly used for killed controls, e.g., when measuring bacterial production indirectly via ${ }^{3} \mathrm{H}$-leucine incorporation (Smith and Azam, 1992), and does not lyse cells.

\section{SEAWATER ACETONE CONCENTRATIONS}

Surface seawater was collected in Niskin bottles, and transferred into brown glass sample bottles with gas-tight stoppers using Tygon $^{\mathrm{TM}}$ tubing. Acetone concentrations were determined using a 
membrane inlet system coupled to a proton transfer reaction mass spectrometer (Beale et al., 2011).

\section{BACTERIAL PRODUCTION, CHLOROPHYLL A CONCENTRATION, AND COMMUNITY COMPOSITION}

Rates of bacterial protein production (BP) and the numbers of heterotrophic bacteria, Synechococcus spp and picoeukaryotes were also determined to investigate any trends. BP was determined by measuring the incorporation of ${ }^{3} \mathrm{H}$-leucine $(20 \mathrm{nM}$ final concentration) into bacterial protein on $1.7 \mathrm{ml}$ seawater samples following the method of Smith and Azam (1992). The numbers of bacterioplankton cells were determined by flow cytometry on SYBR Green I DNA-stained cells from $1.8 \mathrm{ml}$ seawater samples fixed in paraformaldehyde $(0.5-1 \%$, final concentration), flash frozen in liquid nitrogen immediately after fixation, and stored frozen at $-80^{\circ} \mathrm{C}$ (Marie et al., 1997). Numbers of Synechococcus spp and picoeukaryotes were analyzed on unstained samples by flow cytometry (Zubkov et al., 2000). Chlorophyll a samples were determined by fluorometric analysis of acetone-extracted pigments (Holm-Hansen et al., 1965).

\section{RESULTS}

\section{LINEAR TIME COURSE EXPERIMENTS}

When pico-molar concentrations of ${ }^{14} \mathrm{C}$ labeled acetone were added to surface waters from station L4, radioactive carbon was expired to ${ }^{14} \mathrm{CO}_{2}$ (Figure 1) suggesting that acetone was used as a microbial energy source. At this coastal station, acetone oxidation was linear for up to $\sim 3.5 \mathrm{~h}$, after which between 1 and $3.6 \%$ of the added label had been oxidized to ${ }^{14} \mathrm{CO}_{2}$. Microbial acetone oxidation rates were highest in December $2011\left(9.5 \mathrm{pCi} \mathrm{mL}^{-1} \mathrm{~h}^{-1}\right.$, $\left.R^{2}=0.997, n=4\right)$ and lowest during July $2011\left(2.5 \mathrm{pCi} \mathrm{mL}^{-1} \mathrm{~h}^{-1}\right.$, $\left.R^{2}=0.999, n=4\right)$.

\section{UPTAKE KINETICS}

The microbial oxidation of ${ }^{14} \mathrm{C}$ labeled acetone displayed nonsaturation type kinetics for nano-molar additions of acetone between 2 and $47 \mathrm{nmol} \mathrm{L}^{-1}$ during February 2011 (Figure 2A), which, when plotted as a modified Lineweaver-Burke plot (Figure 2C, $\triangle$ ), showed a constant fraction of added label ( $f=0.025 \pm 0.001)$ had been oxidized to $\mathrm{CO}_{2}$, irrespective of the initial addition concentration. Pico-molar ${ }^{14} \mathrm{C}$-acetone additions (6-1006 $\mathrm{pmol} \mathrm{L}^{-1}$ ) were made in the following June which resulted in saturation kinetics (Figure 2B), where the fraction of acetone oxidized reduced from 5.5 to $1.4 \%$ with increasing addition concentrations (Figure 2C; $\mathbf{\Delta}$ ). Saturation kinetics displayed during June 2011 allowed the first estimates of $V_{\max }$ and $K_{\mathrm{m}}$ to be determined from an Eadie-Hofstee plot (Figure 2D) of $4.1 \mathrm{pmol} \mathrm{L}^{-1} \mathrm{~h}^{-1}$ and $54 \mathrm{pmol} \mathrm{L}^{-1}$, respectively, for surface coastal waters of station L4.

\section{SURFACE SEASONAL TRENDS IN MICROBIAL ACETONE OXIDATION}

The average monthly rates of microbial oxidation of acetone in surface waters at station L4 varied between 1.2 and $42 \mathrm{pmol} \mathrm{L}^{-1} \mathrm{~h}^{-1}$
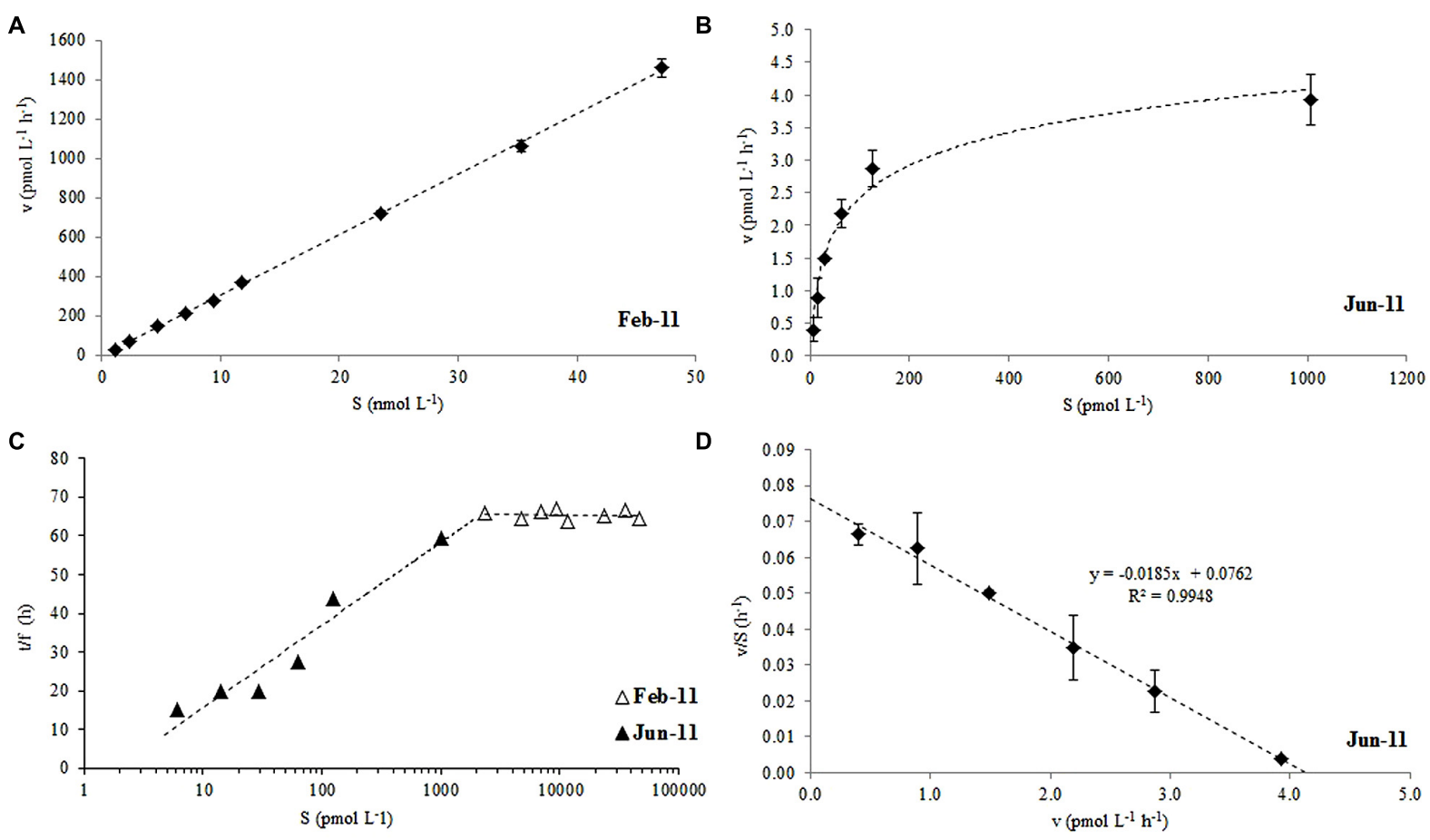

FIGURE 2 | Rate of acetone oxidation (v) against added substrate concentration $\left({ }^{14} \mathrm{C}\right.$-labeled acetone, $\left.\mathrm{S}\right)$ at $(\mathrm{A})$ nano-molar additions in February, (B) pico-molar additions in June, (C) modified Lineweaver-Burke plot of combined Feb and June 2011 data and, (D)

Eadie-Hofstee plot of June data used to derive $\boldsymbol{V}_{\max }$ and $\boldsymbol{K}_{\mathrm{m}}$ for surface waters of station L4. For (C) the time of incubation ( $\mathrm{t}$ ) divided by the fraction of label oxidized to $\mathrm{CO}_{2}$ (f) is plotted against $\mathrm{S}$. The error bars represent \pm 1 standard deviation based on three replicates. 
(Figure 3B) and showed significant changes with season. Oxidation rates were highest during winter (January and February 2011) at $36.2 \pm 8.7 \mathrm{pmol} \mathrm{L}^{-1} \mathrm{~h}^{-1}$ and were 15-fold lower during the summer (June, July, and August 2011) at $2.4 \pm 1.7 \mathrm{pmol} \mathrm{L}^{-1} \mathrm{~h}^{-1}$, with intermediate spring (March, April, May) and autumn (September, October, November) rates averaging $7.5 \pm 4.0$ and $4.5 \pm 0.4$ pmol $\mathrm{L}^{-1} \mathrm{~h}^{-1}$, respectively. When in situ seawater acetone concentrations are divided by microbial oxidation rates, biological turnover times are estimated, ranging between just over 3 days in February to $\sim 243$ days in June during 2011 (Figure 3C). This suggests a clear seasonal trend of longer microbial turnover times in spring and summer months compared to autumn and winter. Corresponding monthly averaged changes in low nucleic acid containing bacteria are also shown in Figure 3C ranging between 0.44 and $3.9 \times 10^{5}$ cells $\mathrm{mL}^{-1}$, which show an opposite trend to microbial acetone turnover times $(r=-0.589, n=16, P<0.02)$. Sea surface temperature at station L4 varied between 8.5 and $16.4^{\circ} \mathrm{C}$, with typical low chlorophyll a values of $\sim 0.4 \mu \mathrm{g} \mathrm{L}^{-1}$ during winter months rising fourfold to $1.6 \mathrm{~g} \mathrm{~L} \mathrm{~L}^{-1}$ in July 2011 (Figure 3A). Additionally, average monthly numbers of high nucleic acid containing bacteria (1.3$5.8 \times 10^{5}$ cells $\left.\mathrm{mL}^{-1}\right)$, Synechococcus sp. $\left(0.7-36 \times 10^{3}\right.$ cells $\left.\mathrm{mL}^{-1}\right)$, pico- $\left(0.6-16 \times 10^{3}\right.$ cells $\left.\mathrm{mL}^{-1}\right)$, and nano- $\left(0.2-1.5 \times 10^{3}\right.$ cells $\left.\mathrm{mL}^{-1}\right)$, phytoplankton cell, and bacterial leucine incorporation rates (8-96 pmol leucine $\mathrm{L}^{-1} \mathrm{~h}^{-1}$ ), are summarized in Table 1.

\section{DEPTH VARIABILITY IN MICROBIAL ACETONE OXIDATION}

The variability of microbial acetone oxidation rates with depth at the relatively shallow $(\sim 55 \mathrm{~m})$ coastal station L4 was investigated during June 2011, when surface rates were at their lowest, but the water column was seasonally stratified (see Figure 4). Microbial acetone oxidation rates were lowest $\left(0.78 \pm 0.02 \mathrm{pmol} \mathrm{L}^{-1} \mathrm{~h}^{-1}\right)$ in the shallow surface layer $(<10 \mathrm{~m})$, which showed enhanced surface warming and relatively lower salinity. Rates were on average, more than $30 \%$ higher at greater depths (average of $1.07 \pm 0.04 \mathrm{pmol}$ $\left.\mathrm{L}^{-1} \mathrm{~h}^{-1}\right)$.

\section{DISCUSSION}

This study shows that ${ }^{14} \mathrm{C}$ labeled acetone can be used successfully to determine microbial oxidation rates (to ${ }^{14} \mathrm{CO}_{2}$ ) in seawater samples. We report the first estimates of $V_{\max }\left(4.1 \mathrm{pmol} \mathrm{L}{ }^{-1} \mathrm{~h}^{-1}\right)$ and $K_{\mathrm{m}}\left(54 \mathrm{pmol} \mathrm{L}^{-1}\right)$ for surface coastal waters during summer, when in situ surface oxidation rates were at their lowest $\left(1.2 \pm 0.39 \mathrm{pmol} \mathrm{L}^{-1} \mathrm{~h}^{-1}\right.$, Figure 3B), despite relatively high average in situ acetone concentrations of $7.5 \pm 0.7 \mathrm{nmol} \mathrm{L}-1$. When nano-molar $(2-47 \mathrm{nM}){ }^{14} \mathrm{C}$ acetone additions were made during winter months, first order kinetics were observed, but Figure 2C shows that a constant fraction of added label was oxidized to $\mathrm{CO}_{2}$, suggesting that any microbial enzyme systems involved in the conversion of acetone to $\mathrm{CO}_{2}$ were saturated. Pico-molar additions made during the summer, when acetone concentrations had more than doubled, showed first order reaction kinetics for approximately $<100$ pM acetone additions (Figure 2B). Both sets of data combined in a modified Lineweaver-Burke plot (Figure 2C, which assumes that if pico-molar additions had been made during winter, similar first order kinetics to summer would be observed) suggest in situ enzyme system saturation of $1-2 \mathrm{nM}$ of mixed natural communities. Although the microbial composition of surface waters at L4 are highly likely to be different between the two seasons (e.g., Gilbert et al., 2009, 2012), it is unknown which microbes actively respire acetone to $\mathrm{CO}_{2}$. However, it is noteworthy that seasonal changes in bacterial structure have been linked to change in day length (Gilbert et al., 2012) and other environmental variables (e.g., temperature, Gilbert et al., 2009) rather than trophic interactions.

The microbial acetone oxidation kinetics observed during February for nano-molar additions does not show rate limitation with increasing substrate concentration, and thus does not comply with Michaelis-Menten kinetics (Wright and Hobbie, 1966), which could indicate no active microbial enzyme transport systems for acetone oxidation. These authors also showed that the slope of such a linear relationship between uptake rates and added substrate concentration (as in Figure 2A) was identical to the kinetics of simple diffusion. In addition, when samples were killed with TCA (5\% final concentration), acetone oxidation did not increase over time, suggesting that, despite a possible lack of active transport systems, the uptake was nevertheless due to microbial metabolic activity. Wright and Hobbie (1966) suggested that at very low concentrations of added substrate, most glucose was incorporated using active bacterial transport systems, while at higher concentrations diffusion across algal cells dominated. Our results suggest that when pico-molar additions are made (June 2011) active transport systems dominated with a resultant mixed community $V_{\max }$ of $4.1 \mathrm{pmol} \mathrm{L}^{-1} \mathrm{~h}^{-1}$ and a $K_{\mathrm{m}}$ of $54 \mathrm{pmol}$ $\mathrm{L}^{-1}$. However when nano-molar additions are made (February 2011) non saturation kinetics were observed, with possible diffusion across cell walls dominating ( $c f$. methanol Dixon et al., 2011a).

Acetone oxidation by natural marine microbial communities could also be due to mixotrophic and heterotrophic phytoplankton in addition to heterotrophic bacteria. For rates of microbial acetone oxidation during February, which increased linearly with substrate concentration $\left(y=0.031 \mathrm{x}-0.003, n=9, R^{2}=0.999\right.$ for $1.7 \mathrm{~h}$ incubation period, Figure 2A) a diffusion constant $\left(K_{\mathrm{d}}\right)$ can be calculated from the slope of the linear relationship (Wright and Hobbie, 1965). This constant assumes that organisms oxidize the acetone as rapidly as it diffuses in (Wright and Hobbie, 1965). A $K_{\mathrm{d}}$ of $0.003 \mathrm{~h}^{-1}$ is equivalent to a turnover time of $\sim 1.4$ days (Wright and Hobbie, 1965) which is comparable to the average estimate of 3.2 days for February 2011 determined in Figure 3C. This also compares well with the turnover of other organic compounds like DMS (e.g., 0.3-2.1 days, Simó et al., 2000) and methanol (e.g., 7 days in productive shelf waters, Dixon et al., 2011a). Despite the faster (i.e., hours) estimated acetone turnover times of de Bruyn et al. (2013), they also reported higher loss rates during the winter compared to other times of the year. However, the acetone turnover times reported by de Bruyn et al. (2013) originate from riverine and very near-shore costal environments (average salinity of $25.8 \pm 2.1$ ), that experience much less seasonal variability (average surface temperature of $17.5 \pm 1.2^{\circ} \mathrm{C}$ ) and higher average in situ acetone concentrations ( $59 \pm 56 \mathrm{nM}$ ) compared to L4 waters (average salinity of $35.2 \pm 0.1$, average surface temperature of $12.5 \pm 2.8^{\circ} \mathrm{C}$, 


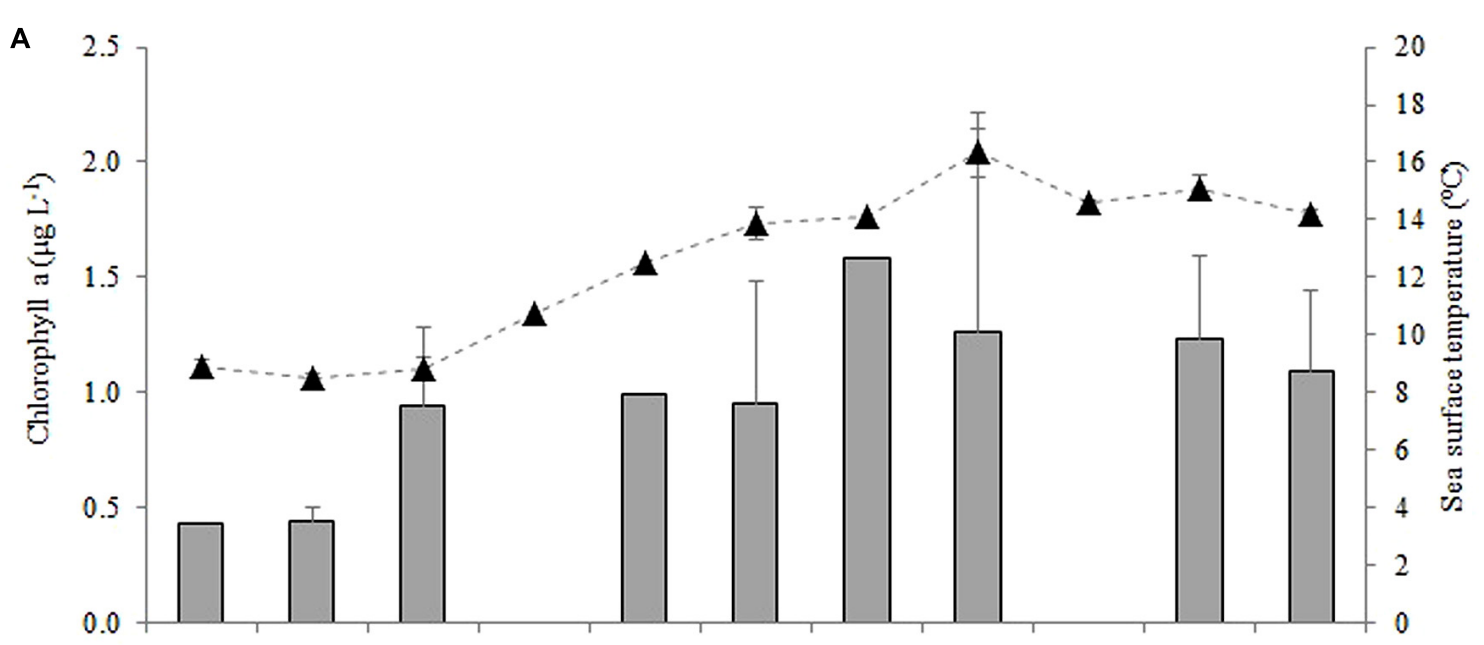

B

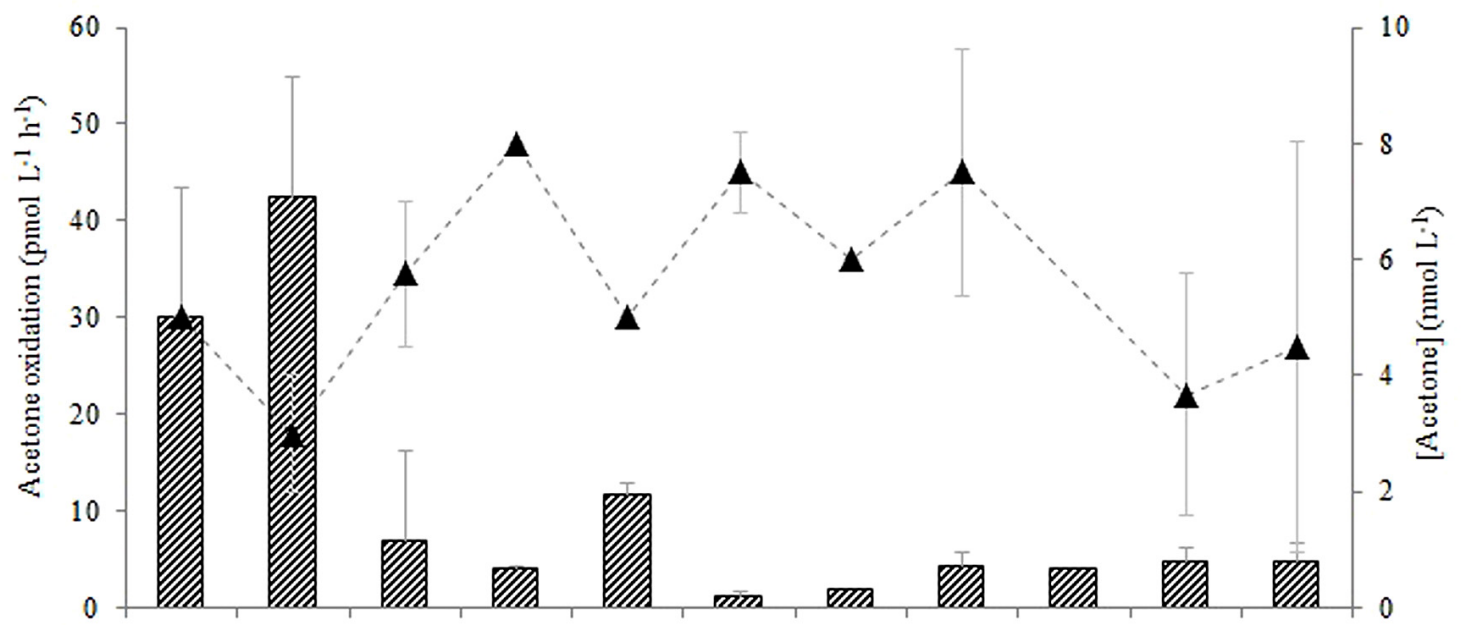

C

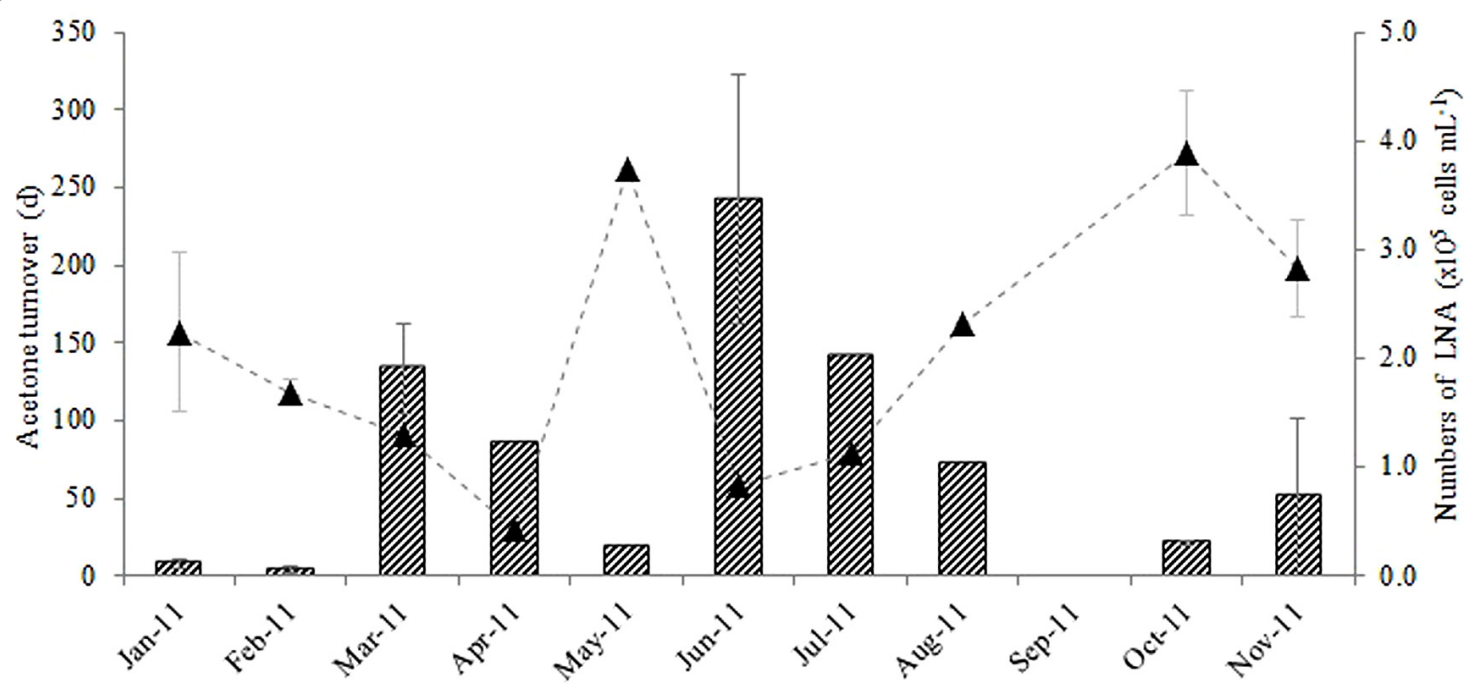

FIGURE 3 | Monthly variability in surface waters at station L4 for (A) chlorophyll a (bars) and sea surface temperature $(\Delta),(B)$ acetone oxidation rates (bars) and in situ seawater acetone concentrations $(\Delta)$ and (C) resulting microbial turnover times (bars) with corresponding changes in the numbers of low nucleic acid containing bacteria ( $\Delta$, LNA where there is a significant linear correlation between the microbial turnover time of acetone and the numbers of low nucleic acid containing bacteria, $r=-\mathbf{0 . 5 8 9}$, $\boldsymbol{n}=\mathbf{1 6}, \boldsymbol{P}<\mathbf{0 . 0 2}$ ). The error bars represent \pm 1 standard deviation based on three replicates. 
average surface acetone concentrations of $5.6 \pm 2.3 \mathrm{nM})$. Furthermore, de Bruyn et al. (2013) report higher acetone loss rates after rain events, which could suggest faster microbial removal associated with less saline waters, although this is not reflected in Figure 4.

Acetone production in seawater is largely thought to be a photochemical process (Kieber et al., 1990; Zhou and Mopper, 1997; de Bruyn et al., 2011; Dixon et al., 2013a), possibly related to UV breakdown of chromophoric dissolved organic matter (CDOM) originating from eukaryotic cells (Dixon et al., 2013a). Given the relatively high microbial acetone oxidation rates found during January/February 2011 (in this study and in de Bruyn et al., 2013), with turnover times estimated at 1.4-3.2 days, it is not presently understood what process maintains acetone levels during winter months, when average acetone concentrations are $3.4 \pm 1.1 \mathrm{nM}$. Typically, during winter at L4, UV levels and phytoplankton biomass are relatively low (e.g., Smyth et al., 2010). However, the water column is fully mixed and more influenced by riverine waters, i.e., maximum river flows and re-suspension events of bottom sediments (Groom et al., 2009). Thus during these periods it is probable that the dissolved organic matter is dominated by terrestrial sources and re-suspended sediments rather than phytoplankton.

Relationships between microbial oxidation and turnover of acetone with other biogeochemical variables (see Table 1) have been explored, and reveal statistically significant negative linear relationships between acetone oxidation rates and both sea surface

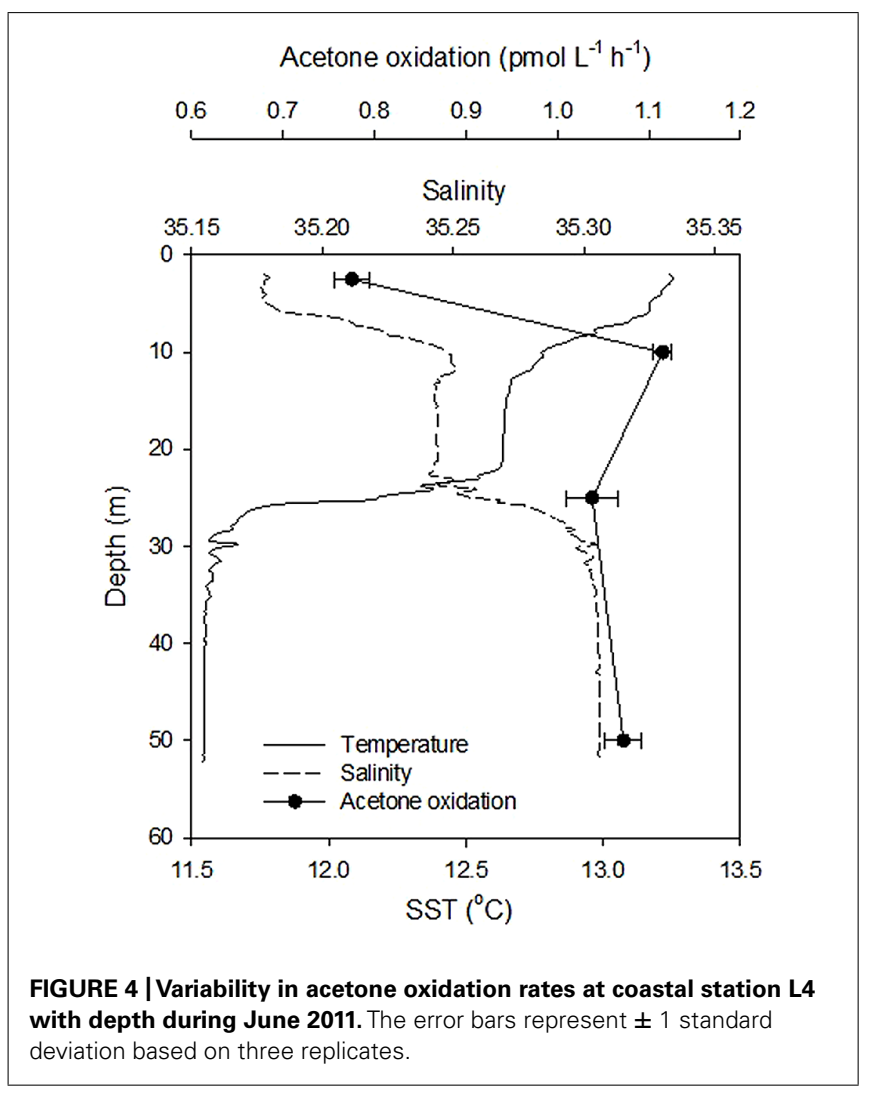

Table 1 | Summary of sampling at coastal station L4.

\begin{tabular}{|c|c|c|c|c|c|c|c|c|}
\hline Month 2011 & $\mathrm{SST}^{\mathrm{a}}\left({ }^{\circ} \mathrm{C}\right)$ & $C h l a^{b}\left(\mu g^{-1}\right)$ & $\begin{array}{l}\text { LNA bacteria }^{c} \\
\left(\times 10^{5} \text { cells }\right. \\
\left.\mathrm{mL}^{-1}\right)\end{array}$ & $\begin{array}{l}\text { HNA bacteria } \\
\left(\times 10^{5} \text { cells }\right. \\
\left.\mathrm{mL}^{-1}\right)\end{array}$ & $\begin{array}{l}\text { Syns }^{\mathrm{e}}\left(\times 10^{3}\right. \\
\left.\text { cells } \mathrm{mL}^{-1}\right)\end{array}$ & $\begin{array}{l}\text { Peuks }^{f} \\
\left(\times 10^{3} \text { cells }\right. \\
\left.\mathrm{mL}^{-1}\right)\end{array}$ & $\begin{array}{l}\operatorname{Nano}^{\mathrm{g}} \\
\left(\times 10^{3} \text { cells }\right. \\
\left.\mathrm{mL}^{-1}\right)\end{array}$ & $\begin{array}{l}\mathrm{BP}^{\mathrm{h}}(\mathrm{pmol} \\
\text { Leu } \\
\left.\mathrm{L}^{-1} \mathrm{~h}^{-1}\right)\end{array}$ \\
\hline \multicolumn{9}{|l|}{ Winter } \\
\hline January & $8.9 \pm 0.3$ & 0.43 & $2.2 \pm 0.73$ & $2.2 \pm 0.70$ & $9.3 \pm 0.14$ & $5.8 \pm 0.77$ & $0.41 \pm 0.08$ & - \\
\hline March & $8.9 \pm 0.4$ & $0.94 \pm 0.34$ & $1.3 \pm 0.1$ & $1.3 \pm 0.02$ & $5.0 \pm 2.3$ & $7.9 \pm 0.31$ & $1.0 \pm 0.46$ & - \\
\hline April & 10.8 & - & 0.44 & 1.8 & 0.74 & 3.0 & 1.3 & 28.6 \\
\hline May & 12.5 & 0.99 & 3.7 & 5.8 & 2.8 & 26.7 & 3.9 & 61.4 \\
\hline \multicolumn{9}{|l|}{ Summer } \\
\hline \multicolumn{9}{|l|}{ Autumn } \\
\hline September & $14.6 \pm 0.1$ & - & - & - & - & - & - & - \\
\hline October & $15.1 \pm 0.4$ & $1.24 \pm 0.36$ & $3.9 \pm 0.6$ & $3.4 \pm 0.72$ & $35.9 \pm 9.8$ & $15.8 \pm 1.9$ & $1.1 \pm 0.09$ & $8.0 \pm 0.02$ \\
\hline November & $14.2 \pm 0.1$ & $1.1 \pm 0.3$ & $2.8 \pm 0.5$ & $2.6 \pm 0.09$ & $13.1 \pm 5.3$ & $7.2 \pm 0.86$ & $0.72 \pm 0.06$ & $10.2 \pm 6.2$ \\
\hline
\end{tabular}

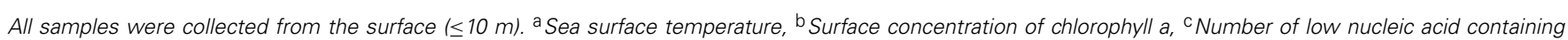

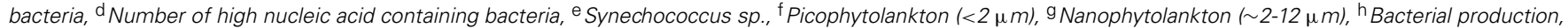

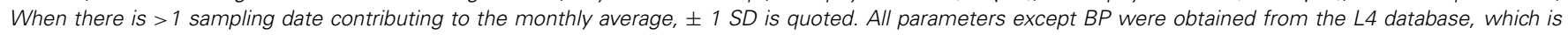
provided by the Plymouth Marine Laboratory, Western Channel Observatory. 
Table 2 | Surface microbial oxidation rates normalized to in situ concentration $\left(\mathrm{h}^{-1}\right)$ and resulting turnover times, as a function of season for coastal station, L4.

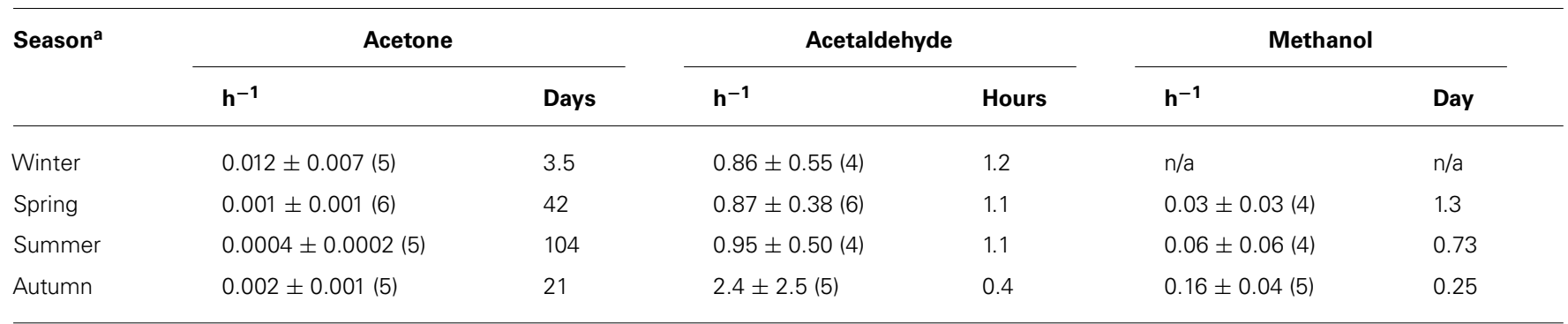

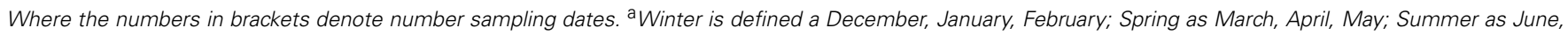
July and August; Autumn as September, October, November during 2011. n/a data not available.

temperature and concentration of chlorophyll $a(r=-0.604$ and -0.543 , respectively for $n=21, P \leq 0.02)$. This is largely because the highest acetone oxidation rates, were found during winter when sea surface temperatures and phytoplankton biomass were at their minima.

A statistically significant inverse relationship was also found between biological acetone turnover times and the numbers of low nucleic acid bacteria (LNA, $r=-0.589, n=16, P<0.02$ ). As previously noted, we do not know which marine microbes are capable of utilizing acetone, or the enzyme system(s) involved in the conversion of acetone to $\mathrm{CO}_{2}$, but this relationship indicates that low nucleic acid containing bacteria could be responsible for marine acetone consumption in surface coastal waters. SAR11 Alphaproteobacteria, are often significant components of the LNA (Mary et al., 2006) and are the most abundant heterotrophs in the oceans. SAR11 cells are believed to play a major role in mineralizing dissolved organic carbon (Sun et al., 2011) being efficient competitors for resources (Morris et al., 2002). Whilst in culture, Sun et al. (2011) found that Candidatus Pelagibacter ubique (a subgroup of SAR11) have the genome encoded pathways for the oxidation of a variety of one-carbon compounds, including the OVOC compound methanol. We found that the SAR11 clade were the second most numerically dominant bacterial order of surface bacterial populations found at station L4 during the annual sampling period 2011-2012, and contributed between 16 and 46\% during winter months (Sargeant, 2014). Alphaproteobacteria were also the most abundant bacterial Class found at station L4 over a 6 year study (Gilbert et al., 2012). This study further reported that members of the Rickettsiales (SAR11) and Rhodobacteriales were the most frequently recorded operational taxonomic units, with the abundance of Rickettsiales reaching a maxima in winter (Gilbert et al., 2012), coincident with relatively fast acetone turnover times of $\sim 3$ days, found in this study.

The acetone biological turnover times determined here should be considered as conservative, because it is possible that some heterotrophic bacteria also assimilate acetone carbon into particulate carbon biomass $c f$. methanol, Dixon et al. (2013b). Furthermore, microbial acetone uptake that gets transformed and excreted as more refractory DOC compounds (as in the microbial carbon pump, e.g., Ogawa et al., 2001; Jiao and Azam, 2011), possibly via some overflow metabolism strategies as previously suggested for methanol (Dixon et al., 2013a) will also not be revealed via the experimental approach of this study.

Coastal surface water microbial acetone oxidation rates have been normalized to in situ concentration as a function of season, and are compared to other biologically utilized OVOC compounds (acetaldehyde and methanol, e.g., Dixon et al., 2013a) in Table 2. Acetone is a less preferred organic compound for marine microbes compared to methanol and acetaldehyde, although acetone oxidation rates shows a much more pronounced seasonality. In addition, the one depth profile undertaken during summer suggests near-surface reduction in microbial acetone oxidation rates associated with a less saline, warmer tongue of water in the top $10 \mathrm{~m}$.

The kinetic characteristics of microbial acetone oxidation can be compared to those of other substrates commonly used by bacteria, so that the ecological significance of acetone to marine microbial metabolism can be evaluated. Both $V_{\max }$ and $K_{\mathrm{m}}$ are more than 2 orders of magnitude smaller for acetone oxidation compared to methanol oxidation (Dixon et al., 2011a), which if compared further with proteins and carbohydrates gives the following order; proteins $>>$ carbohydrates $\approx$ methanol $>>$ acetone (refer to Dixon etal., 2011a for protein, carbohydrate, and methanol $V_{\max }$ and $K_{\mathrm{m}}$ data).

This research offers the first comprehensive seasonally resolved study combining microbial acetone oxidation rates with in situ concentrations in order to derive biological turnover times that ranged between $\sim 3$ days in winter to $>240$ days in summer. We have experimentally derived the first $V_{\max }$ and $K_{\mathrm{m}}$ estimates of microbial acetone oxidation. We have also highlighted that there must be an unrecognized production mechanism for acetone during winter in coastal regions, possibly relating in some way, to enhanced dissolved organic matter from terrestrial sources. Further research should investigate possible winter acetone production mechanisms, identify which microbial species are utilizing acetone in marine environments, and characterize what enzyme systems are involved in the oxidation process.

\section{ACKNOWLEDGMENTS}

We wish to thank Denise Cummings for chlorophyll a analysis at L4, which is provided by the Plymouth Marine Laboratory Western Channel Observatory (www.westernchannelobservatory.org.uk), 
and is funded by the NERC national capability. This work was funded by OCEANS 2025, Plymouth Marine Laboratory NERC funded core research programme.

\section{REFERENCES}

Ashraf, W., Mihdhir, A., and Murrell, J. C. (1994). Bacterial oxidation of propane. FEMS Microbiol. Lett. 122, 1-6. doi: 10.1111/j.1574-6968.1994.tb07134.x

Beale, R., Dixon, J. L., Arnold, S. R., Liss, P. S., and Nightingale, P. D. (2013). Methanol, acetaldehyde and acetone in the surface waters of the Atlantic Ocean. J. Geophys. Res. Oceans 118, 5412-5425. doi: 10.1002/jgrc.20322

Beale, R., Liss, P. S., Dixon, J. L., and Nightingale, P. D. (2011). Quantification of oxygenated volatile organic compunds in seawater by membrane inlet-Proton transfer reaction mass spectrometry. Anal. Chim. Acta 706, 128-134. doi: 10.1016/j.aca.2011.08.023

Connell, T., Joye, S. B., Miller, L. G., and Oremland, R. S. (1997). Bacterial oxidation of methyl bromide in Mono Lake, California. Environ. Sci. Technol. 31, 1489-1495. doi: $10.1021 / \mathrm{es} 960732 \mathrm{k}$

de Bruyn, W. J., Clark, C. D., Pagel, L., and Singh, H. (2013). Loss rates of acetone in filtered and unfiltered coastal seawater. Mar. Chem. 150, 39-44. doi: 10.1016/j.marchem.2013.01.003

de Bruyn, W. J., Clark, C. D., Pagel, L., and Takehara, C. (2011). Photochemical production of formaldehyde, acetaldehyde and acetone from chromophoric organic matter in coastal waters. J. Photochem. Photobiol. A Chem. 226, 16-22. doi: 10.1016/j.jphotochem.2011.10.002

Dixon, J. L., Beale, R., and Nightingale, P. D. (2011a). Microbial methanol uptake in northeast Atlantic waters. ISME J. 5, 704-716. doi: 10.1038/ismej.2010.169

Dixon, J. L., Beale, R., and Nightingale P. D. (2011b). Rapid biological oxidation of methanol in the tropical Atlantic: significance as a microbial carbon source. Biogeosciences 8, 2707-2716. doi: 10.5194/bg-8-2707-2011

Dixon, J. L., Beale, R., and Nightingale, P. D. (2013a). Production of methanol, acetaldehyde and acetone in the Atlantic Ocean. Geophys. Res. Lett. 40, 4700-4705. doi: 10.1002/grl.50922

Dixon, J. L., Sargeant, R. S., Nightingale, P. D., and Murrell, J. C. (2013b). Gradients in microbial methanol uptake: productive coastal upwelling waters to oligotrophic gyres in the Atlantic Ocean. ISME J. 7, 568-580. doi: 10.1038/ismej. 2012.130

Dixon, J. L., and Nightingale, P. D. (2012). Fine scale variability in methanol uptake and oxidation in the micro-layer and near-surface waters of the Atlantic. Biogeosciences 9, 2961-2972. doi: 10.5194/bg-9-2961-2012

Fischer, E. V., Jacob, D. J., Millet, D. B., Yantosca, R. M., and Mao, J. (2012). The role of the ocean in the global atmospheric budget of acetone. Geophys. Res. Lett. 39, L01807. doi: 10.1029/2011GL050086

Gilbert, J. A., Field, D., Swift, P., Newbold, L., Oliver, A., Smyth, T., et al. (2009). The seasonal structure of microbial communities in the Western English Channel. Environ. Microb. 11, 3132-3139. doi: 10.1111/j.1462-2920.2009.02017.x

Gilbert, J. A., Steele, J. A., Caporaso, J. G., Steinbrück, L., Reeder, J., Temperton, B., et al. (2012). Defining seasonal marine microbial community dynamics. ISME J. 6, 298-308. doi: 10.1038/ismej.2011.107

Goodwin, K. D., Schaefer, J. K., and Oremland, R. S. (1998). Bacterial oxidation of dibromomethane and methyl bromide in natural waters and enrichement cultures. Appl. Environ. Microbiol. 64, 4629-4636.

Groom, S., Martinez-Vicente, V., Fishwick, J., Tilstone, G., Moore, G., Smyth, T., et al. (2009). The western English Channel observatory: Optical characteristics of station L4. J. Mar. Syst. 77, 278-295. doi: 10.1016/j.jmarsys.2007.12.015

Hartmans, S., and de Bont, J. A. M. (1986). Acetol monooxygenase from Mycobacterium Pyl cleaves acetol into acetate and formaldehyde. FEMS Microbiol. Lett. 36, 155-158. doi: 10.1111/j.1574-6968.1986.tb01686.x

Holm-Hansen, O., Lorenzen, C. J., Holmes, R. W., and Strickland, J. D. H. (1965). Fluorometric determinations of chlorophyll. J. Conseil Permen. Int. l'Explorat. Mer. 30, 3-15. doi: 10.1093/icesjms/30.1.3

Jacob, D. J., Field, B. D., Jin, E. M., Bey, I., Li, Q., Logan, J. A., etal. (2002). Atmospheric budget of acetone. J. Geophys. Res. 107, 694. doi: 10.1029/2001JD000694

Jiao, N., and Azam, F. (2011). "Microbial carbon pump and its significance for carbon sequestration in the ocean," in Microbial Carbon Pump in the Ocean, eds N. Jiao, F. Azam, and S, Sanders (Washington, DC: Science/AAAS), 43-45.

Kieber, R. J., Zhou, X. L., and Mopper, K. (1990). Formation of carbonyl compounds from UV-induced photodegradation of humic substances in natural waters: Fate of riverine carbon in the sea. Limnol. Oceanogr. 35, 1503-1515. doi: 10.4319/lo.1990.35.7.1503

Kiene, R. P., and Hoffmann Williams, L. P. (1998). Glycine betaine uptake, retention, and degradation by microorganisms in seawater. Limnol. Oceanogr. 43, 15921603. doi: 10.4319/lo.1998.43.7.1592

Lewis, A. C., Hopkins, J. R., Carpenter, L. J., Stanton, J., Read, K. A., and Pilling, M. J. (2005). Sources and sinks of acetone, methanol, and acetaldehyde in North Atlantic marine air, Atmos. Chem. Phys. 5, 1963-1974. doi: 10.5194/acp-5-19632005

Marandino, C. A., De Bruyn, W. J., Miller, S. D., Prather, M. J., and Saltzman, E. S. (2005). Oceanic uptake and the global atmospheric acetone budget. Geophys. Res. Lett. 32, 285. doi: 10.1029/2005GL023285

Marie, D., Partensky, F., Jacquet, S., and Vaulot, R. (1997). Enumeration and cell analysis of natural populations of marine picoplankton by flow cytometry using the nucleic acid strain SYBR Green I. Appl. Environ. Microbiol. 63, 186-193.

Mary, I., Cummings, D. G., Biegala, I. C., Burkill, P. H., Archer, S. A., and Zubkov, M. V. (2006). Seasonal dynamics of bacterioplankton structure at a coastal station in the western English Channel. Aquat. Microb. Ecol. 42, 119-126. doi: 10.3354/ame042119

Mopper, K., and Stahovec, W. L. (1986). Sources and sinks of low molecular weight carbonyl compunds in seawater. Mar. Chem. 19, 305-321. doi: 10.1016/03044203(86)90052-6

Mopper, K., Zhou, X., Kieber, R. J., Kieber, D. J., Sikorski, R. J., and Jones, R. D. (1991). Photochemical degradation of dissolved organic carbon and its impact on the oceanic carbon cycle. Nature 353, 60-62. doi: 10.1038/353060a0

Morris, R. M., Rappe, M. S., Connon, S. A., Vergin, K. L., Siebord, W. A., Carlson, C. A., et al. (2002). SAR11 clade dominates ocean surface bacterioplankton communities. Nature 420, 806-810. doi: 10.1038/nature01240

Nemecek-Marshall, M., Wojciechowski, C., Kuzma, J., Silver, G. M., and Fall, R. (1995). Marine vibrio species produce the volatile organic compound acetone. Appl. Environ. Microbiol. 61, 44-47.

Ogawa, H., Amagai, Y., Koike, I., Kaiser, K., and Benner, R. (2001). Production of refractory dissolved organic matter by bacteria. Science 292, 917-920. doi: 10.1126/science.1057627

Rathbun, R. E., Stephens, D. W., Shultz, D. J., and Tai, D. Y. (1982). Fate of acetone in water. Chemosphere 11, 1097-1114. doi: 10.1016/0045-6535(82)90114-X

Read, K. A., Carpenter, L. J., Arnold, S. R., Beale, R., Nightingale, P. D., Hopkins, J. R., et al. (2012). Multiannual observations of acetone, methanol, and acetaldehyde in remote tropical Atlantic air: Implications for atmospheric OVOC budgets and oxidative capacity. Environ. Sci. Technol. 46, 11028-11039. doi: $10.1021 / \mathrm{es} 302082 \mathrm{p}$

Sargeant, S. (2014). Microbial Utilisation of Methanol in Seawater. Ph.D. thesis, University of Warwick, Warwick.

Simó, R., Pedrós-Alió, C., Malim, G., and Grimalt, J. O. (2000). Biological turnover of DMS, DMSP and DMSO in contrasting open-sea waters. Marine Ecol. Progr. Series 203, 1-11. doi: 10.3354/meps203001

Singh, H. B., Kanakidou, M., Crutzen, P. J., and Jacob, D. J. (1995). High concentrations and photochemical fate of oxygenated hydrocarbons in the global troposhere. Nature 378, 51-54. doi: 10.1038/378050a0

Singh, H. B., Salas, L. J., Chatfield, R. B., Czech, E., Fried, A., Walega, J., et al. (2004). Analysis of the atmospheric distribution, sources and sinks of oxygenated volatile organic chemicals based on measurements over the Pacific during TRACE-P. J. Geophys. Res. 109, D15S07. doi: 10.1029/2003JD003883

Singh, H., Chen, Y., Staudt, A., Jacob, D., Blake, D., Heikes, B., et al. (2001). Evidence from the Pacific troposphere for large global sources of oxygenated organic compounds. Nature 410, 1078-1081. doi: 10.1038/350 74067

Singh, H., Chen, Y., Tabazadeh, T., Fukui, Y., Bey, I., Yantosca, R., et al. (2000). Distribution and fate of selected oxygenated organic species in the troposphere and lower stratosphere over the Atlantic. J. Geophys. Res. 105, 3795-3805. doi: 10.1029/1999JD900779

Singh, H., Tabazadeh, A., Evans, M. J., Field, B. D., Jacob, D. J., Sachse, G., et al. (2003). Oxygenated volatile organic chemicals in the oceans: inferences and implications based on atmospheric obseravtions and air-sea exchange models. Geophys. Res. Lett. 30, 1862. doi: 10.1029/2003GL017933

Sluis, M. K., and Ensign, S. A. (1997). Purification and characterisation of acetone carboxylase from Xanthobacter strain Py2. Proc. Natl. Acad. Sci. U.S.A. 94, 84568461. doi: 10.1073/pnas.94.16.8456 
Smith, D. C., and Azam, F. (1992). A simple, economical method for measuring bacterial protein synthesis rates in seawater using $3 \mathrm{H}$-leucine. Mar. Microb. Food Webs 6, 107-114.

Smyth, T. J., Fishwick, J. R., Al-Moosawi, L., Cummings, D. G., Harris, C., Kitidis, V., etal. (2010). A broad spatio-temporal view of the Western English Channel observatory. J. Plantk. Res. 32, 585-601. doi: 10.1093/plankt/ fbp 128

Sun, J., Steindler, L., Thrash, J. C., Halsey, K. H., Smith, D. P., Carter, A. E., et al. (2011). One carbon metabolism in SAR11 pelagic marine bacteria. PLoS ONE 6:e23973. doi: 10.1371/journal.pone.0023973

Taddei, S., Toscano, P., Gioli, B., Matese, A., Miglietta, F., Vaccari, F. P., et al. (2009). Carbon dioxide and acetone air-sea fluxes over the Southern Atlantic. Environ. Sci. Technol. 43, 5218-5222. doi: 10.1021/es8032617

Wennberg, P. O., Hanisco, T. F., Jaeglé, L., Jacob, D. J., Hintsa, E. J., Lanzendorf, E. J., et al. (1998). Hydrogen radicals, nitrogen radicals, and the production of ozone in the upper troposphere. Science 279,49-53. doi: 10.1126/science.279.5347.49

Williams, J., Holzinger, R., Gros, V., Xu, X., Atlas, E., and Wallace D. W. R. (2004). Measurements of organic species in air and seawater from the tropical Atlantic. Geo. Res. Lett. 31, L23S06 doi: 10.1029/2004GL020012

Wright, R. T., and Hobbie, J. E. (1965). The uptake of organic solutes in lake water. Limnol. Oceanogr. 10, 22-28. doi: 10.4319/lo.1965.10.1.0022

Wright, R. T., and Hobbie, J. E. (1966). Use of glucose and acetate by bacteria and algae in aquatic ecosystems. Ecology 47,447-464. doi: 10.2307/1932984
Zhou, X., and Mopper, K. (1997). Photochemical production of low molecularweight carbonyl compounds in seawater and surface microlayer and their air sea exchange. Mar. Chem. 56, 201-213. doi: 10.1016/S0304-4203(96)00076-X

Zubkov, M. V., Sleigh, M. A., Burkill, P. H., and Leakey R. J. G. (2000). Picoplankton community structure on the Atlantic Meridional Transect: a comparison between seasons. Prog. Oceanogr. 45, 369-386. doi: 10.1016/S0079-6611(00)00008-2

Conflict of Interest Statement: The authors declare that the research was conducted in the absence of any commercial or financial relationships that could be construed as a potential conflict of interest.

Received: 10 March 2014; accepted: 05 May 2014; published online: 26 May 2014. Citation: Dixon JL, Beale R, Sargeant SL, Tarran GA and Nightingale PD (2014) Microbial acetone oxidation in coastal seawater. Front. Microbiol. 5:243. doi: 10.3389/fmicb. 2014.00243

This article was submitted to Terrestrial Microbiology, a section of the journal Frontiers in Microbiology.

Copyright (c) 2014 Dixon, Beale, Sargeant, Tarran and Nightingale. This is an openaccess article distributed under the terms of the Creative Commons Attribution License (CC BY). The use, distribution or reproduction in other forums is permitted, provided the original author(s) or licensor are credited and that the original publication in this journal is cited, in accordance with accepted academic practice. No use, distribution or reproduction is permitted which does not comply with these terms. 